\section{PENINGKATAN KEAKTIFAN DAN HASIL BELAJAR MATEMATKA MELALUI METODE DEMONSTRASI}

\section{Biodata Penulis}

Nama Lenkap

Tempat/tanggal lahir

Email

Alamat

: SUPRAPTI, S.Pd.SD.

: Cilacap, 20 Desember 1971

: suprapti022@guru.sd.belajar.id

: Desa Canduk rt.03, rw.05, Lumbir, Banyumas, Jawa Tengah

Riwayat Pekerjaan

1. 1995 - 2004 : Guru SDN 01 Jambu Kecamatan Wangon Kabupaten Banyumas

2. 2005 - 2021 : Guru SD Negeri di wilayah Kecamatan Jeruklegi Kabupaten Cilacap

Riwayat Pendidikan

1. SD : SDN Paatimuan 18 Kecamatan Kedungreja Kabupaten Cilacap

2. SMP : SMP Negeri 02 Wangon Kecamatan Wangon Kabupaten Banyumas

3. SPG : SPG Negeri Cilacap

4. DII : IKIP Jakarta

5. SI : PGSD UT

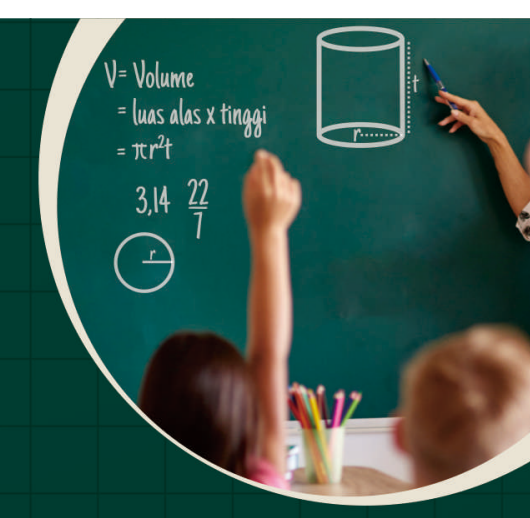

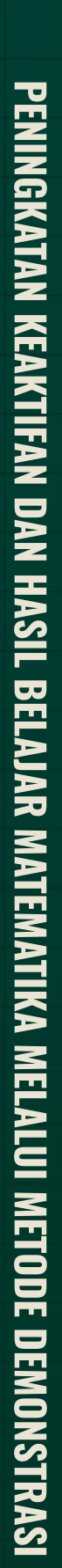

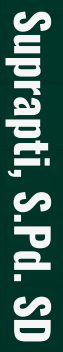
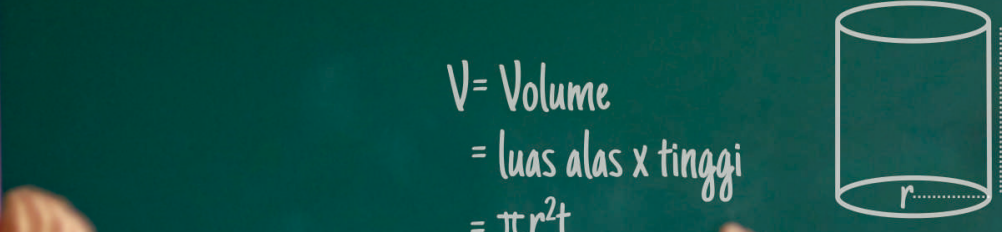

$=\pi r^{2} t$

$3,14 \frac{22}{7}$ $r$

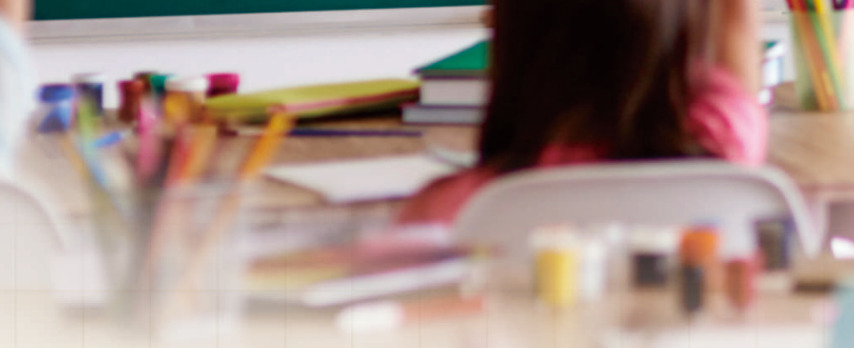

Suprapti, S.Pd. SD

PENINGKATAN KEAKTIFAN DAN HASIL BELAJAR MATEMATIKA MELALUI METODE DEMONSTRASI

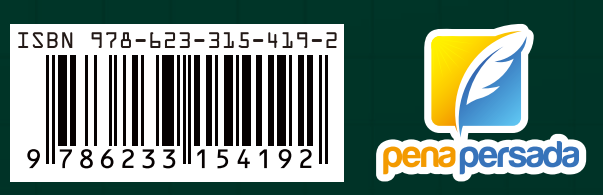




\section{PENINGKATAN KEAKTIFAN \\ DAN HASIL BELAJAR MATEMATIKA MELALUI METODE DEMONSTRASI}

SUPRAPTI, S.Pd. SD

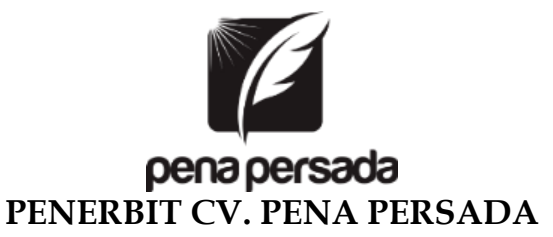




\title{
PENINGKATAN KEAKTIFAN \\ DAN HASIL BELAJAR MATEMATIKA \\ MELALUI METODE DEMONSTRASI
}

\author{
Penulis: \\ Suprapti, S.Pd. Sd \\ ISBN: 978-623-315-419-2 \\ Editor: \\ Rusfik Yulli Anur Wati \\ Design Cover: \\ Retnani Nur Briliant
}

Layout:

Nisa Falahia

\section{Penerbit CV. Pena Persada}

Redaksi:

Jl. Gerilya No. 292 Purwokerto Selatan, Kab. Banyumas

Jawa Tengah

Email: penerbit.penapersada@gmail.com

Website: penapersada.com Phone: (0281) 7771388

\section{Anggota IKAPI}

All right reserved

Cetakan pertama: 2021

Hak Cipta dilindungi oleh undang-undang. Dilarang memperbanyak karya tulis ini dalam bentuk apapun tanpa izin penerbit 


\section{KATA PENGANTAR}

Segala puji senantiasa kita panjatkan kehadirat Allah Swt, atas segala rahmat dan karunianya, akhirnya penulis dapat menyelesaikan penyusunan buku yang berjudul "Peningkatan Keaktifan dan Hasil Belajar Matematika Melalui Metode Demonstrasi". Saya menyadari bahwa tanpa bantuan dan bimbingan dari berbagai pihak sangatlah sulit bagi saya untuk menyelesaikan karya ini. Oleh karena itu, saya mengucapkan banyak terima kasih pada semua pihak yang telah membantu penyusunan buku ini. Sehingga buku ini bisa hadir di hadapan pembaca.

Dalam buku ini membahas tentang peningkatan keaktifan dan hasil belajar matematika pada materi menghitung volume tabung melalui metode demonstrasi bagi siswa kelas VI SD Negeri Jambusari 03 Kecamatan Jeruklegi Kabupaten Cilacap Tahun 2015/ 2016. Pendidikan merupakan kunci untuk semua kemajuan dan perkembangan yang berkualitas, sebab dengan pendidikan manusia dapat mewujudkan semua potensi dirinya baik sebagai pribadi maupun sebagai warga masyarakat. Untuk dapat mencapai tujuan tersebut, seorang guru harus mampu menumbuhkan motivasi peserta didik agar memiliki semangat dan kemauan belajar yang lebih tinggi. Dalam pembelajaran matematika tentang menentukan volume tabung merupakan hal yang sangat bermanfaat dalam kehidupan sehari-hari, agar siswa mampu menghitung isi sebuah bangun ruang tabung yang ada di kehidupannya, guru harus mampu mengorganisasi perencanaan dan pelaksanaan pembelajaran, agar berjalan efektif dan optimal, sehingga tujuan yang ingin dicapai dapat tercapai.

Penulis menyadari bahwa buku ini masih jauh dari kesempurnaan. Oleh karena itu kritik dan saran yang membangun sangat dibutuhkan guna penyempurnaan buku ini. Akhir kata saya berharap Allah Swt berkenan membalas segala kebaikan semua pihak yang telah membantu

\section{Penulis}




\section{DAFTAR ISI}

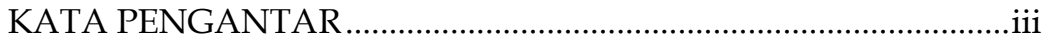

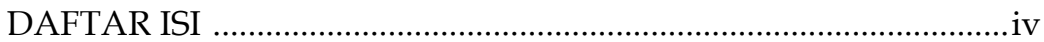

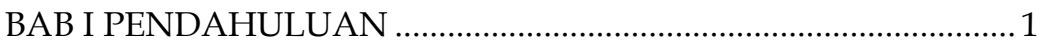

A. Peran Guru dalam Tercapainya Tujuan Pendidikan ......... 1

B. Pentingnya Menyusun Strategi Pembelajaran ..................... 3

BAB II PENINGKATAN KEAKTIFAN DAN HASIL BELAJAR SISWA

A. Keaktifan dan Hakikat Belajar ............................................. 6

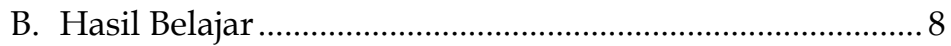

C. Hakekat Belajar Matematika ................................................ 11

D. Metode Demonstrasi ............................................................15

BAB III METODE DEMONSTRASI DALAM MENENTUKAN

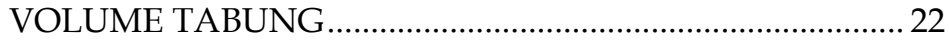

A. Langkah-langkah dalam Metode Demonstrasi ............... 22

B. Tahapan Perbaikan Pembelajaran .................................... 24

1. Kegiatan Pra Siklus ........................................................ 24

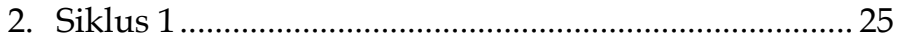

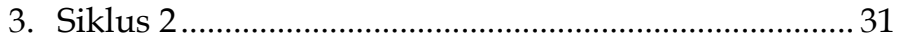

BAB IV PERBAIKAN PEMBELAJARAN DALAM KELAS.............. 37

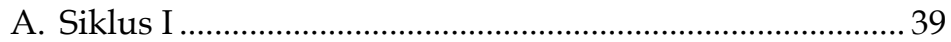

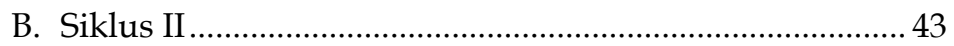

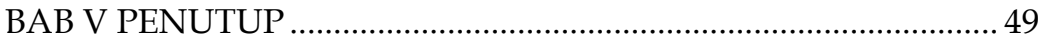

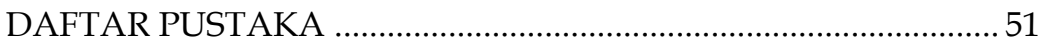

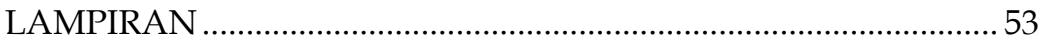




\section{BAB I \\ PENDAHULUAN}

\section{A. Peran Guru dalam Tercapainya Tujuan Pendidikan}

Pendidikan merupakan kunci untuk semua kemajuan dan perkembangan yang berkualitas, sebab dengan pendidikan manusia dapat mewujudkan semua potensi dirinya baik sebagai pribadi maupun sebagai warga masyarakat. Berdasarkan hasil observasi dapat ditengarai bahwa aspek proses dan hasil pembelajaran merupakan salah satu penyebab perlunya ditingkatkan mutu pendidikan. Kualitas proses dan hasil belajar mengajar yang rendah menunjukkan bahwa interaksi antara siswa dengan sumber belajar seperti dengan guru dan lingkungan tidak berjalan efektif sehingga hasil belajar yang dicapai tidak optimal.

Guru merupakan salah satu unsur yang penting dalam pencapaian tujuan pendidikan. Crow and Crow (1957) dalam Hera Lestari Mikarsa (2007:1.3) mengemukan: harus diyakini bahwa fungsi utama pendidikan adalah bimbingan terhadap individu dalam upaya memenuhi kebutuhan dan keinginan yang sesuai dengan potensi yang dimilikinya sehingga dia memperoleh kepuasan dalam seluruh aspek kehidupan pribadi dan kehidupan sosialnya. Guru adalah pembimbing untuk mengarahkan peserta didik ke tujuan yang benar agar peserta didik mampu meraih prestasi yang gemilang yang berguna bagi dirinya maupun orang lain.

Tujuan pendidikan adalah menyiapkan peserta didik agar dapat berperan penting dalam kehidupannya di masa yang akan datang. Tentunya dalam hal ini guru memiliki peran penting menciptakan peserta didik menjadi manusia yang berbudi pekerti luhur dan mempunyai intelektual yang tinggi yang berfungsi untuk mengembangkan potensi yang bermanfaat bagi kehidupan pribadinya maupun bagi warga 
negara atau warga masyarakat lainnya di masa yang akan datang.

Sekolah merupakan salah satu lembaga pendidikan formal yang berfungsi sebagai sarana bagi siswa, untuk menuntut ilmu yang berguna bagi kehidupannya sebagai bekal untuk memecahkan berbagai persoalan dalam kehidupan mereka di masa yang akan datang, dan guru sebagai ujung tombak dari lembaga pendidikan dituntut untuk mampu mengorganisasikan dan menyelenggarakan proses pembelajaran yang sesuai dengan kemajuan jaman.

Untuk dapat mencapai tujuan pendidikan guru harus mampu menumbuhkan motivasi peserta didik agar memiliki semangat dan kemauan belajar yang lebih tinggi. Tanpa motivasi peserta didik tidak akan mampu mengembangkan potensi dirinya. Dengan demikian faktor motivasi memegang peranan yang tidak dapat diabaikan dalam menjaga kelangsungan belajar peserta didik, untuk mencapai tingkat kesungguhan belajar yang tinggi. Salah satu tindakan yang baik untuk memotivasi peserta didik adalah membangkitkan minat peserta didik. Minat merupakan salah satu kunci utama untuk memperlancar peserta didik dalam memahami dan mempelajari sesuatu.

Untuk membangkitkan minat dalam proses pembelajaran di kelas guru harus mampu menggunakan berbagai strategi dalam setiap proses pembelajaran, agar dapat tercipta suasana belajar yang lebih kondusif, peserta didik merasa senang, dan merasa bergairah mengikuti semua proses pembelajaran, sehingga menjadikan belajar merupakan suatu kebutuhan. Agar dapat tercipta hal tersebut seorang guru dalam mengajar harus melakukan dengan sungguh-sungguh, penuh tanggung jawab dan menjadikan mengajar suatu kewajiban yang menyenangkan, sehingga mengajar sebagai tugas utama seorang guru bukan merupakan beban yang berat. 


\section{B. Pentingnya Menyusun Strategi Pembelajaran}

Di era kemajuan ilmu dan teknologi seperti sekarang ini kehidupan di dunia selalu berkembang, terutama semakin pesatnya perkembangan teknologi informasi dalam kehidupan, yang menyebabkan arus komunikasi menjadi pesat dan tanpa batas. Hal ini berdampak pada dunia pendidikan ekonomi dan norma kehidupan seperti tersingkirnya tenaga kerja yang kurang berpendidikan dan kurang terampil, terkikisnya budaya lokal dan pergaulan bebas. Dengan demikian siswa perlu memiliki kemampuan memperoleh, memilih dan mengolah informasi untuk bertahan pada keadaan yang selalu berubah, tidak pasti dan kompetitif. Dengan demikian siswa perlu memiliki kesiapan untuk menghadapi berbagai perubahan dikehidupannya dengan bertindak atas dasar pemikiran logis, rasional, kritis, cermat, jujur, disiplin, kreatif dan efektif. Cara berpikir seperti ini dapat dikembangkan melalui belajar matematika, karena menurut Karso, dkk (2004:2.6) "Penggunaan matematika sebagai alat untuk memecahkan masalah dalam mata pelajaran lain, kehidupan kerja, atau dalam kehidupan sehari-hari".

Pada zaman sekarang guru betul-betul dituntut keberhasilannya dalam proses pembelajaran matematika karena Mata Pelajaran Matematika adalah mata pelajaran yang di Ujian Nasionalkan. Mata Pelajaran Matematika merupakan salah satu mata pelajaran penentu untuk masuk sekolah negeri ke tingkat yang lebih tinggi. Dengan demikian mata pelajaran matematika sangat dikehendaki keberhasilannya tidak hanya untuk memenuhi Kriteria Ketuntasan Minimal (KKM) dan memenuhi tujuan para insan pendidik tapi juga oleh para orang tua sebagai syarat untuk mempermudah melanjutkan sekolah anaknya ke jenjang yang lebih tinggi.

Mata Pelajaran Matematika bagi siswa SD sangat berguna untuk kepentingan hidup dalam lingkungannya, untuk mengembangkan pola pikirnya, menumbuhkembangkan kemampuan, membentuk pribadi serta sebagai dasar untuk mempelajari ilmu-ilmu yang lain. Untuk dapat 
mengembangkan hal tersebut tidak lepas dari peran serta guru, karena guru sebagai pembimbing dan pendidik, tentunya dengan kepiawaian guru sebagai guru yang profesional.

Banyak strategi yang dapat diterapkan guru dalam menyampaikan proses pembelajaran agar proses pembelajaran lebih kondusif misalnya menggunakan metode yang tepat, ataupun penggunaan media yang sesuai. Dalam pemilihan strategi tentunya guru harus menyesuaikan dengan materi, begitu juga dalam penggunaan media harus sesuai dengan pesan yang akan disampaikan. Guru yang profesional adalah guru yang mampu mengelola kelas dengan baik. Mengelola dalam bidang administrasi maupun mengelola proses pembelajaran. Hera Lestari Mikarsa (2007:1.8) “Guru yang profesional dan kompeten adalah guru yang menguasai pembelajaran matematika, memahami bagaimana anak-anak belajar menguasai pembelajaran yang mampu mencerdaskan peserta didik, dan mempunyai kepribadian yang dinamis dalam membuat keputusan perencanan dan pelaksanaan pembelajaran".

Dari pendapat tersebut sudah jelas bahwa seorang guru harus mampu menguasai seluruh kegiatan dalam proses pembelajaran dari perencanaan sampai dengan pelaksanaan.

Seperti halnya pembelajaran matematika tentang menentukan volume tabung yang sangat bermanfaat dalam kehidupan sehari-hari, agar siswa mampu menghitung isi sebuah bangun ruang tabung yang ada dikehidupannya, guru harus mampu mengorganisasi perencanaan dan pelaksanaan pembelajaran, agar berjalan efektif dan optimal, sehingga tujuan yang ingin dicapai dapat tercapai. Namun pada kenyataannya dalam pembelajaran matematika SD, guru sering menghadapi kendala, siswa sering takut menghadapi Mata Pelajaran Matematika. Terkadang siswa tidak masuk sekolah karena takut ada pelajaran matematika. Siswa sering malas apabila mengikuti pelajaran matematika. Apabila diadakan angket mata pelajaran yang disukai dan tidak disukai ternyata 
sebagian besar siswa akan menulis Mata Pelajaran Matematika yang tidak disukai.

Melalui identifikasi diketahui ketakutan siswa terhadap matematika karena guru dalam pembelajaran tidak menciptakan suasana yang belajar yang kondusif sehingga siswa merasa stress menghadapi matematika.

Siswa tidak senang dengan matematika karena siswa menganggap matematika sulit dipahami, menganggap pelajaran matematika suatu hal yang menakutkan. Ketakutan siswa didukung dengan gurunya yang menekan siswa untuk menghafal rumus-rumus tanpa penanaman konsep yang tepat, sehingga siswa benci dengan pelajaran matematika bahkan siswa tidak hanya benci pelajaran matematika gurunya pun ikut dibenci. Hal seperti itu terjadi bukan kesalahan siswa, tapi kesalahan guru karena cara menyampaikan pembelajaran matematika guru sering membosankan, guru dalam menyampaikan pembelajaran matematika sering tidak menggunakan metode yang tepat dan media yang sesuai.

Seperti yang terjadi di kelas penulistindask yaitu di Kelas VI SD Negeri Jambusari 03 dalam mata pelajaran matematika tentang menentukan volume tabung, guru belum mampu meningkatkan keaktifan dan hasil belajar siswa, hal ini terbukti dari hasil ulangan pada kondisi awal keaktifan dan hasil belajar siswa masih rendah. Banyak siswa yang mendapat nilai di bawah Kriteria Ketuntasan Minimal (KKM) yaitu nilai yang sudah ditetapkan oleh sekolah 65 (enam puluh lima). Dari 43 siswa hanya 13 atau $30 \%$ siswa yang tuntas belajar dan 30 atau $70 \%$ siswa belum tuntas belajar. Keaktifan siswa dalam mengikuti pembelajaran hanya 15 siswa atau 35\% siswa yang aktif. Sehingga nilai rata-rata kelas masih jauh di bawah Kriteria Ketuntasan Minimal (KKM). Dampak dari kondisi yang demikian apabila dibiarkan maka pembelajaran akan semakin terpuruk dan tujuan pembelajaran tidak tercapai sesuai yang diharapkan. 


\section{BAB II \\ PENINGKATAN KEAKTIFAN \\ DAN HASIL BELAJAR SISWA}

\section{A. Keaktifan dan Hakikat Belajar}

Menurut Kamus Bahasa Indonesia (Dendy Sugono, 2008:

31) Keaktifan adalah kegiatan, kesibukan yang membuat hasil belajarnya sangat gemilang.

Menurut Gagne (1984), dalam Udin S. Winataputra, M.A.,dkk. (2004:2.3) mengatakan bahwa belajar adalah suatu proses dimana suatu organisme berubah perilakunya sebagai akibat pengalaman. Sedangkan M. Surya, dkk (2004:8.4) mengemukakan "Belajar adalah suatu proses yang dilakukan oleh individu untuk memperoleh suatu perubahan tingkah laku yang baru secara keseluruhan, sebagai hasil dari pengalaman individu itu sendiri dalam interaksi dengan lingkungannya".

Berdasarkan pengertian belajar tersebut maka dapat disimpulkan bahwa dengan belajar akan terjadi proses perubahan mental dan emosional, berfikir dengan perasaan aktif yang hanya dapat dirasakan oleh yang bersangkutan melalui pengalaman belajar, dan perubahan perilaku tersebut tidak dapat diamati oleh guru sendiri.

Dalam perubahan tingkah laku guru tidak bisa mengamati perubahan dalam kemampuan aktivitas fikiran dan perasaan siswa, tetapi guru hanya bisa mengamati aktivitas kegiatan siswa yang merupakan akibat dari aktivitas perasaan dan fikiran siswa.

Kemudian Fontana (1981) dalam Udin S. Winataputra, dkk. (2008:1.8) Mengartikan belajar adalah suatu perubahan relatif tetap dalam perilaku individu sebagai hasil pengalaman. Sedangkan Gagne (1985) dalam Udin S. Winataputra, dkk. (2008:1.8) juga menyatakan bahwa belajar adalah suatu perubahan dalam kemampuan yang bertahan lama dan bukan berasal dari proses pertumbuhan. Sedangkan Bower dan 
Hilgrad (1981) dalam Udin S. Winataputra, dkk. (2008:1.8) mengemukakan yaitu bahwa belajar mengacu pada perubahan perilaku atau potensi individu sebagai hasil dari pengalaman dan perubahan tersebut tidak disebabkan oleh insting, kematangan, kelelahan atau kebiasaan. Dari pengertian tersebut sudah jelas bahwa belajar merupakan penambahan ilmu, belajar tidak hanya berkenaan dengan jumlah pengetahuan yang dipelajari tetapi perluasan, dan pendalaman pengetahuan, nilai, dan sikap serta keterampilan. Dalam belajar tidak hanya perubahan satu-persatu tetapi meliputi keseluruhan kemampuan individu, dan belajar mempunyai ciri-ciri:

1. Belajar terjadi perubahan perilaku individu.

2. Perubahan perilaku merupakan hasil dari pengalaman.

3. Perubahan perilaku relatif tetap.

Roger (Anthoni J. Sutich dan miles A. Vich, 1969) dalam Hera Lestari Mikarsa (2007:6.7) mengemukakan prinsip-prinsip belajar sebagai berikut:

1. Manusia mempunyai dorongan alamiah untuk belajar, dorongan ingin tahu, melakukan eksplorasi, dan mengasimilasi pengalaman baru.

2. Belajar akan bermakna apabila materi yang dipelajari relevan dengan kebutuhan anak.

3. Belajar harus diperkuat dengan jalan mengurangi ancaman eksternal seperti hukuman, penilaian, sikap merendahkan murid, mencemoohkan dan sebagainya.

4. Belajar atas inisiatif sendiri akan melibatkan keseluruhan pribadi baik faktor internal maupun eksternal.

5. Sikap mandiri, kreativitas, dan percaya diri diperkuat dengan penilaian atas diri sendiri.

Dengan demikian hal ini sikap guru memiliki peranan yang sangat penting agar hasil belajar dapat dirasakan oleh individu dalam hal ini siswa, karena belajar bermakna adalah belajar yang dapat dirasakan oleh siswa dan yang dapat memenuhi kebutuhan nyata individu. 
Sedangkan Menurut Asep Herry Hernawan (2008:2.13) prinsip belajar sebagai berikut:

1. “Belajar itu berdasarkan keseluruhan.

2. Belajar adalah pembentukan kepribadian.

3. Belajar berkat pemahaman.

4. Belajar berdasarkan pengalaman.

5. Belajar adalah suatu proses perkembangan.

6. Belajar adalah proses kesinambungan.

7. Belajar akan lebih berhasil jika dihubungkan dengan minat, perhatian, dan kebutuhan siswa".

Berbagai faktor yang dapat mempengaruhi terjadinya proses belajar sehingga belajar lebih bermakna adalah

1. Motivasi siswa dalam mengikuti pembelajaran yang berdampak pada keaktifan siswa.

2. Perhatian pada pelajaran, semakin besar perhatian siswa maka hasil yang dicapai dalam proses pembelajaran semakin baik.

3. Aktivitas mental dan emosional terlibat dalam pembelajaran.

Motivasi, perhatian, dan aktivitas yang dimiliki siswa sangat berperan penting dalam pembelajaran, apabila hal tersebut dapat terpelihara dengan baik maka proses pembelajaran dapat berjalan dengan optimal yang akan berakibat hasil belajar yang maksimal.

\section{B. Hasil Belajar}

Hasil belajar siswa adalah suatu hasil yang diinginkan guru dalam setiap pembelajaran. Guru yang profesional adalah guru yang selalu berusaha meningkatkan hasil belajar, karena dengan hasil belajar yang meningkat maka siswa akan mendapat prestasi meningkat pula.

Bukti bahwa seseorang telah belajar adalah adanya hasil belajar yang ditandai dengan terjadinya perubahan tingkah laku pada orang tersebut, misalnya dari tidak tahu menjadi tahu, dan dari tidak mengerti menjadi mengerti (Hamalik, 2008). 
Menurut Bloom, dkk dalam Asep Herry Hernawan, dkk (2008:10.23) Tujuan atau hasil belajar digolongkan menjadi 3 domain yaitu domain kognitif, afektif, dan psikomotor.

Tipe belajar kognitif berkenaan dengan perkembangan penalaran otak dan kemampuan siswa dalam belajar. Tipe belajar afektif akan tampak pada tingkah laku siswa seperti semangat belajar, perhatian pada pelajaran dan untuk mengetahui peningkatan memiliki disiplin, adanya motivasi dan hasil belajar berupa aktivitas yang tinggi. Tipe psikomotor akan tampak pada bentuk keterampilan siswa dalam kemampuan bertindak.

Sedangkan menurut Suprijono (2009) Hasil belajar adalah pola-pola perbuatan, nilai-nilai, pengertian-pengertian, sikap-sikap, apresiasi, dan keterampilan. Merujuk pemikiran Gagne, hasil belajar berupa:

1. Informasi verbal yaitu kapabilitas mengungkapkan pengetahuan dalam bentuk bahasa, baik lisan maupun tertulis.

2. Keterampilan intelektual yaitu kemampuan mempresentasikan konsep dan lambang.

3. Strategi kognitif yaitu kecakapan menyalurkan dan mengarahkan aktivitas kognitifnya sendiri. Kemampuan ini meliputi penggunaan konsep dan kaidah dalam memecahkan masalah.

4. Keterampilan motorik yaitu kemampuan melakukan serangkaian gerak jasmani dalam urusan dan koordinasi, sehingga terwujud otomatisme gerak jasmani.

5. Sikap adalah kemampuan menerima atau menolak objek berdasarkan penilaian terhadap objek tersebut. Sikap berupa kemampuan menginternalisasi dan eksternalisasi nilai-nilai. Sikap merupakan kemampuan menjadikan nilai-nilai sebagai standar perilaku.

Hasil belajar digunakan oleh guru untuk dijadikan ukuran atau kriteria dalam mencapai suatu tujuan pendidikan. Howard Kingsley membagi 3 macam hasil belajar (1) Keterampilan dan kebiasaan (2) Pengetahuan dan pengertian 
(3) Sikap dan cita-cita. Hasil belajar merupakan gambaran kemampuan siswa dalam memenuhi suatu tahapan pencapaian pengalaman belajar dalam satu kompetensi dasar (Sanjaya, 2005).

Berdasarkan pengertian di atas maka dapat disimpulkan bahwa hasil belajar adalah suatu penilaian akhir dari proses pembelajaran ditandai perubahan perilaku secara keseluruhan tidak hanya pada satu aspek potensi kemanusiaan saja karena turut serta dalam membentuk kepribadian seseorang.

Menurut Ahmadi (2008) faktor-faktor yang mempengaruhi proses dan hasil belajar adalah:

1. Faktor raw input (yakni faktor murid/anak itu sendiri) adalah kondisi individu atau anak yang belajar itu sendiri. Faktor individu dapat dibagi menjadi dua bagian:

a. Kondisi fisiologis, seperti kesehatan dan cacat tubuh.

b. Kondisi psikologis, beberapa faktor psikologis yang dianggap utama dalam mempengaruhi proses dan hasil belajar yaitu: minat, kecerdasan, bakat, motivasi dan kemampuan-kemampuan kognitif.

2. Faktor environmental input (yakni faktor lingkungan), dapat berupa lingkungan alami ataupun lingkungan sosial, baik yang berwujud manusia maupun hal-hal lainnya, juga dapat mempengaruhi proses dan hasil belajar, seperti suara mesin pabrik, hiruk pikuk lalu lintas dan lain-lain.

3. Faktor instrumental input adalah faktor yang keberadaan dan penggunaannya dirancangkan sesuai dengan hasil belajar diharapkan, dapat berwujud faktor-faktor keras (hardware), seperti gedung perlengkapan belajar, alat-alat praktikum, perpustakaan dan sebagainya, maupun faktor-faktor lunak (software), seperti kurikulum, guru (pengajar), bahan/ program yang harus dipelajari, pedoman-pedoman belajar dan sebagainya

Hasil belajar biasanya menggunakan penilaian. Dengan penilaian guru akan mengetahui meningkat tidaknya hasil belajar Menurut Udin S. Winataputra, dkk. (2004:1.35) "Penilaian hasil belajar adalah upaya 
mengumpulkan informasi untuk mengetahui seberapa jauh kemampuan yang telah dicapai siswa pada setiap akhir pembelajaran". Sedangkan menurut Asep Herry Hernawan, dkk (2008:10.28) "Hasil belajar evaluasi adalah hasil belajar yang menunjukkan kemampuan memberikan keputusan tentang nilai sesuatu berdasarkan pertimbangan yang dimiliki atau kriteria yang digunakan yaitu kriteria yang dikembangkan sendiri dan kriteria yang diberikan oleh guru".

Kurikulum 2004 (2004:351) penilaian hasil berfungsi belajar sebagai:

a. alat penjamin, pengawasan, dan pengendalian mutu pendidikan;

b. bahan pertimbangan dalam penentuan kenaikan kelas, kelulusan, dan tamat belajar siswa pada sekolah;

c. bahan pertimbangan masuk jenjang pendidikan yang lebih tinggi;

d. umpan balik dalam perbaikan program pembelajaran pada sekolah;

e. alat pendorong dalam meningkatkan kemampuan siswa.

Penilaian dilakukan melalui tes tertulis, tes lisan, tes perbuatan/praktik, pemberian tugas, dan kumpulan hasil kerja siswa/portofolio. Penilaian ini untuk mengukur tingkat kemampuan siswa dalam penguasaan materi yang telah diberikan guru dalam proses pembelajaran.

\section{Hakekat Belajar Matematika}

Menurut Suwangsih dan Tiurlina (2006:4), ada beberapa definisi mengenai matematika yang dikemukakan oleh para ahli, antara lain :(1) Russefendi, matematika terorganisasi dari unsur-unsur yang tidak didefinisikan, definisi-definisi, aksioma-aksioma, dan dalil-dalil setelah dibuktikan kebenarannya berlaku secara umum, karena itulah matematika sering disebut ilmu deduktif. (2)James dan James, matematika adalah ilmu tentang logika, mengenai bentuk, susunan, besaran, dan konsep-konsep yang berhubungan satu dengan 
yang lainnya. Matematika terbagi dalam tiga bagian besar yaitu aljabar, analisis dan geometri. (3) Johnson dan Rising dalam Russefenndi, matematika adalah pola berpikir, pola mengorganisasikan, pembuktian yang logis, matematika itu adalah bahasa yang menggunakan istilah yang didefinisikan dengan cermat, jelas dan akurat representasinya dengan simbol dan padat, lebih berupa bahasa simbol mengenai ide daripada mengenai bunyi. (4) Reys-dkk, matematika adalah telaahan tentang pola dan hubungan, suatu jalan atau pola berpikir, suatu seni, suatu bahasa dan suatu alat. (5) Kline, matematika itu bukan pengetahuan menyendiri yang dapat sempurna karena dirinya sendiri, tetapi adanya matematika itu terutama untuk membantu manusia dalam memahami dan menguasai permasalahan sosial, ekonomi, dan alam.

Sedangkan hakikat matematika menurut Soedjadi dalam Heruman (2007:1), yaitu memiliki objek tujuan abstrak, bertumpu pada kesepakatan, dan pola pikir yang deduktif.

Dari uraian di atas, bahwa matematika adalah ilmu yang berkenaan dengan ide atau konsep yang tersusun secara hirarkis dan penalaran deduktif yang tujuannya untuk melatih cara berpikir dan bernalar, mengembangkan aktivitas kreatif, mengembangkan kemampuan memecahkan masalah, dan mengembangkan kemampuan menyampaikan informasi.

Belajar matematika bagi siswa SD merupakan suatu pembentukan pola pikir anak dalam pemahaman dan penalaran. Menurut Udin S. Winataputra, dkk. (2004:1.25) "Mata pelajaran matematika berfungsi mengembangkan kemampuan berkomunikasi dengan menggunakan bilangan dan simbol-simbol serta ketajaman penalaran yang dapat membantu memperjelas menyelesaikan permasalahan dalam kehidupan sehari-hari".

Pembelajaran matematika sangat bermanfaat bagi siswa karena siswa dapat mengetahui tentang bilangan dan simbol yang dapat digunakan untuk berkomunikasi dalam kehidupan sehari-hari, sehingga dapat membantu siswa dalam mengembangkan penalarannya untuk memecahkan masalah 
dalam kehidupan sehari-hari. Sedangkan kegiatan pembelajaran pada hakikatnya adalah proses komunikasi mengirim dan menerima pesan dan media sebagai wahana informasi pembelajaran dari sumber pesan yaitu guru yang akan disampaikan kepada siswa si penerima pesan, sedangkan metode sebagai cara yang digunakan guru dalam proses pembelajaran sehingga proses pembelajaran bermakna bagi siswa.

Menurut William Brownel (1935) dalam Karso, dkk. (2004:1.22) mengatakan bahwa belajar itu pada hakekatnya merupakan suatu proses bermakna. Ia mengemukakan bahwa belajar matematika itu harus merupakan belajar bermakna dan pengertian.

Berdasarkan teori tersebut sudah jelas bahwa belajar matematika siswa harus melihat makna dari apa yang dipelajari sehingga siswa mengerti. Untuk dapat melihat makna apa yang dipelajari perlunya banyak latihan dengan strategi pembelajaran yang sesuai dengan tingkat perkembangan intelektual siswa atau tingkat perkembangan berpikir anak agar pembelajaran berjalan efektif dan efisien.

Dalam belajar matematika banyak materi yang dapat dipelajari diantaranya tentang bangun ruang. Bangun ruang adalah benda yang beraturan bentuknya dan di dalamnya berongga, berkerangka, memiliki sisi, titik sudut, dan rusuk.

Banyak bentuk-bentuk bangun ruang diantaranya bangun ruang tersebut adalah kubus, balok, tabung, limas, prisma, kerucut, bola. Menurut M Khalid Suyati (2004:241):

1. "Kubus yaitu sebuah bangun ruang 6 sisi, 12 rusuk, dan 8 titik sudut sisi-sisinya berbentuk persegi 6 yang berhadapan sama luasnya.

2. Balok yaitu sebuah bangun ruang 6 sisi, 12 rusuk, dan 8 titik sudut sisi-sisinya berbentuk persegi panjang sisi-sisi yang berhadapan sama luasnya.

3. Tabung yaitu sebuah benda ruang yang mempunyai alas dan tutup berbentuk lingkaran dan mempunyai selimut 
tabung yang berupa sebuah bidang dan jarak lingkaran atas dan lingkaran tutup yang disebut tinggi tabung".

Gambar bangun ruang sebagai berikut:

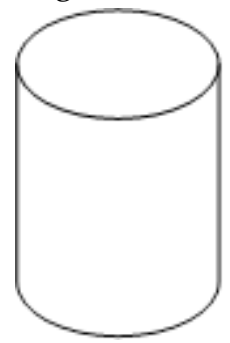

Tabung

Dalam pembelajaran matematika terdapat materi tentang volume. Definisi volume menurut Gatot Muhsetyo, dkk (2008:6.8) "volume adalah suatu ukuran yang menyatakan besar suatu bangun ruang".

Volume merupakan suatu ukuran bangun ruang menurut Gatot Muhsetyo, dkk (2008:6.8) “Mengukur volume berarti membandingkan besar sesuatu dengan sesuatu yang mempunyai besar tertentu".

Tabung dapat dipandang sebagai suatu prisma dengan bentuk alas berupa suatu lingkaran.

Menurut Gatot Muhsetyo, dkk (2008:6.16) "Karena alas tabung berbentuk lingkaran dan rumus luas lingkaran untuk jari-jari $r$ adalah $\pi r^{2}$ maka rumus untuk volume tabung dapat dinyatakan dalam bentuk:

$$
\begin{aligned}
\mathrm{V} & =\text { Volume } \\
& =\text { luas alas } \mathrm{x} \text { tinggi } \\
& =\pi r^{2} \mathrm{t}
\end{aligned}
$$

Perlu diketahui $\pi$ (pi) adalah suatu bilangan tetap yang merupakan nilai perbandingan antara keliling lingkaran dengan garis tengah (diameter) lingkaran nilai $\pi$ mendekati 3,14 atau juga dapat dinyatakan dengan $\frac{22}{7}$. Jadi volume tabung 
yang jari-jari lingkaran atasnya dinyatakan dengan $\mathrm{r}$ dan tingginya dinyatakan dengan $\mathrm{t}$ adalah: $\mathrm{V}=$ volume tabung

$$
\begin{aligned}
& \mathrm{V}=3,14 \times r^{2} \times \mathrm{t} \quad(\text { bila } \pi=3,14) \\
& \text { atau } \\
& \mathrm{V}=\frac{22}{7} \times r^{2} \times \mathrm{t} \quad\left(\text { bila } \pi=\frac{22}{7}\right)
\end{aligned}
$$

Pembelajaran matematika adalah proses pemberian pengalaman belajar kepada peserta didik melalui serangkaian kegiatan terencana sehingga peserta didik memperoleh kompetensi yang dipelajari. Salah satu yang menentukan ketercapaian kompetensi adalah penggunaan strategi pembelajaran matematika.

Raka Joni (1980) dalam kurikulum 2004 (2004:318) strategi adalah pola umum perbuatan guru-siswa di dalam perwujudan kegiatan belajar mengajar.

Guru yang profesional dan kompeten adalah guru yang mampu menguasai materi pembelajaran matematika, mampu menggunakan berbagai strategi dalam pembelajaran matematika yang sesuai dengan materi yang akan diajarkan, memahami bagaimana yang disenangi anak-anaknya dalam belajar, dalam pembelajaran selalu berusaha mencerdaskan peserta didik, dan mempunyai kepribadian yang dinamis dalam membuat perencanaan dan pelaksanaan pembelajaran.

\section{Metode Demonstrasi}

Proses pembelajaran adalah cara siswa memperoleh pengalaman belajar dan suatu proses individu mengubah tingkah lakunya dalam upaya memenuhi kebutuhannya, serta upaya untuk mencapai tujuan. Dalam upaya mencapai hal tersebut siswa perlu bantuan guru sebagai pendidik dan pembimbing, dengan demikian guru harus memiliki kemampuan mengolah proses pembelajaran sehingga bermakna bagi siswa. 